Jelena Avdalović1*, Srdjan Miletić ${ }^{1}$, Mila llić ${ }^{1}$, Jelena Milić1, Tatjana Šolević Knudsen ${ }^{1}$, Aleksandra Djurić ${ }^{3}$, Dejan Nešković ${ }^{2}$, Miroslav Vrvić ${ }^{3}$

${ }^{1}$ University of Belgrade, Institute for Chemistry, Technology and Metallurgy, Belgrade, Serbia, ${ }^{2}$ University of Belgrade, Faculty of Mining and Geology, Belgrade, Serbia, ${ }^{3}$ University of Belgrade, Faculty of Chemistry, Belgrade, Serbia
Scientific paper

ISSN 0351-9465, E-ISSN 2466-2585

UDC:628.112.036

doi:10.5937/ZasMat1603389A

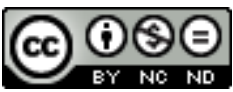

Zastita Materijala 57 (3)

389 - 396 (2016)

\title{
Monitoring of underground water - necessary step in determining the method for site remediation
}

\begin{abstract}
The object of this study was to investigate the quality of underground water on the location of heating plant "Novi Beograd" (Serbia). The examination included a system of 10 piezometers ( $P 1$, $P 5, P 6, P 7, P 8, P 9, P 10, P 11, P 12, P 13)$, which are constructed in two cycles $(P 1, P 5, P 6$ and $P 13$ are located at depth of up to $10 \mathrm{~m}$, and $P 7$ to $P 12$ are located at depth of up to $15 \mathrm{~m}$ ). Obtained results indicate that the area $P 5$ to $P 8$, as well as $P 12$ and $P 13$, has a concentration of total petroleum hydrocarbons greater that the remediation value standardized as $0,6 \mathrm{mg} / \mathrm{L}$. It was also determined that the total volume of the contaminated underground water is around 105.000 $\mathrm{m}^{3}$. All of the above indicates that it is necessary to start the remediation of underground water contaminated with petroleum hydrocarbons and that the most appropriate remediation procedure for this site is in situ bioremediation.
\end{abstract}

Keywords: underground water, remediation, petroleum hydrocarbon.

\section{INTRODUCTION}

During the regular underground water quality control on the location of heating plant (HP) "Novi Beograd", which is under the authority of Public Utility Enterprise "Beogradske Elektrane", it was discovered that piezometers had a strong odour characteristic for petroleum derivates, as well as an increase in concentration of mineral oils. Since there was a suspicion that an environmental incident has occurred, quality of underground water on the site of HP "Novi Beograd" was examined, together with samples from Sava River in the zone of the oil depot, in order to determine the quantity and the degree of potential pollution.

In order to successfully realize the above-said goal, it was necessary to perform the following tasks:

1. Sample the water from piezometers and from Sava River as well, between the river bank and the dock;

\footnotetext{
${ }^{*}$ Corresponding author: Jelena Avdalović

E-mail: javdalovic@chem.bg.ac.rs

Paper received: 13. 02. 2015.

Paper accepted: 10. 03. 2016.

Paper is available on the website: www.idk.org.rs/journal
}

2. Analyze the physical, physicochemical, chemical and microbiological parameters in water samples;

3. Determine the type and the extent of pollution.

4. Based on the obtained results, propose the most appropriate method for remediation of the contaminated area.

The purpose of this examination, beside the understanding the current situation in the area of HP "Novi Beograd", was to enable the safe management of the pollution, first of all in relation to the environmental protection of drinking water sources.

\section{EXPERIMENTAL}

\subsection{Temperature}

Temperature of air and liquid samples was measured on site by using digital thermometer "Elite", manufactured by "HANNA Instruments" (Padova, Italia).

\subsection{Turbidity}

Turbidity was determined by using CHEMetrics Turbidity Meter instrument, according to the manufacturer's instructions.

\subsection{Conductivity and total dissolved solids}

Conductivity in liquid samples was measured by conductometer model 44600 Conductivity/TDS Meter, manufactured by "HACH company" 
(Loveland, USA), and Total dissolved solids (TDS) were measured by using the same instrument in "TDS" mode.

\subsection{Dissolved oxygen}

Dissolved oxygen was measured directly in liquid samples immediately after sampling by digital oximeter (type Oxi 330i) manufactured by "WTW" (Weilhem, Germany) with membrane electrode.

\subsection{Electrochemical measurements}

Potentiometric and $\mathrm{pH}$ measurements were monitored in the same electrochemical cell, equipped with Fisher platinum electrode and reference saturated calomel electrode (SCE) for potentiometric measurements and with a glass electrode for monitoring $\mathrm{pH}$. A digital $\mathrm{mV} / \mathrm{pH}$ Hanna instruments voltmeter was used for all $\mathrm{pH}$ and potentiometric measurements.

\subsection{Total petroleum hydrocarbon}

Total petroleum hydrocarbon (TPH) from groundwater samples were extracted as per method ISO 9377-2 [1]. Samples were analyzed on an Agilent $7890 \AA$ gas chromatograph with a flame ionization detector (FID), equipped with a chromatographic column HP-5, length $30 \mathrm{~m}$ and diameter $0,32 \mathrm{~mm}$, the thickness of the stationary phase $0,25 \mu \mathrm{m}$. The carrier gas is hydrogen with a flow rate of $2 \mathrm{~mL} / \mathrm{min}$, injector temperature is 250 ${ }^{\circ} \mathrm{C}$ and the detector temperature is $320{ }^{\circ} \mathrm{C}$. Temperature program: initial temperature of $40{ }^{\circ} \mathrm{C}$ during $1 \mathrm{~min}$., then heated to $100^{\circ} \mathrm{C}$ at a rate of 15 ${ }^{\circ} \mathrm{C} / \mathrm{min}$., and then to a temperature of $310^{\circ} \mathrm{C}$ is 10 ${ }^{\circ} \mathrm{C} / \mathrm{min}$ and finally isothermal $310^{\circ} \mathrm{C}$ for 15 minutes. The software that was used for data processing is ChemStation, Agilent Technologies.

\subsection{Fourier-transform infrared spectroscopy}

Fourier-transform infrared (FT-IR) spectra of TPH were obtained on a Nicolet 6700 FT-IR Spectrometer (Thermo scientific, USA) equipped with Omnic software.

\subsection{The number of microorganisms}

The number of microorganisms was determined by plating appropriate serial dilutions on agar plates incubated at $28{ }^{\circ} \mathrm{C}$. The media used were nutrient agar for total chemoorganoheterotrophs (TC) and mineral base medium [2] containing $2 \mathrm{~g}$ of standard D2 diesel fuel in $1 \mathrm{dm}^{3}$ of medium [3] was used for microorganisms which degrade hydrocarbons (HD).

\section{RESULTS AND DISCUSSION}

The examination included a system of 10 piezometers (P1, P5, P6, P7, P8, P9, P10, P11, P12, $\mathrm{P} 13)$, constructed in two cycles (P1, P5, P6 and $\mathrm{P} 13$ are located at depth of up to $10 \mathrm{~m}$ and $\mathrm{P} 7$ to $\mathrm{P} 12$ are located at depth of up to $15 \mathrm{~m}$ ) [4]. Water from Sava River was sampled from the surface in the area between the river bank and the dock. The locations of the piezometers are shown in Figure 1.

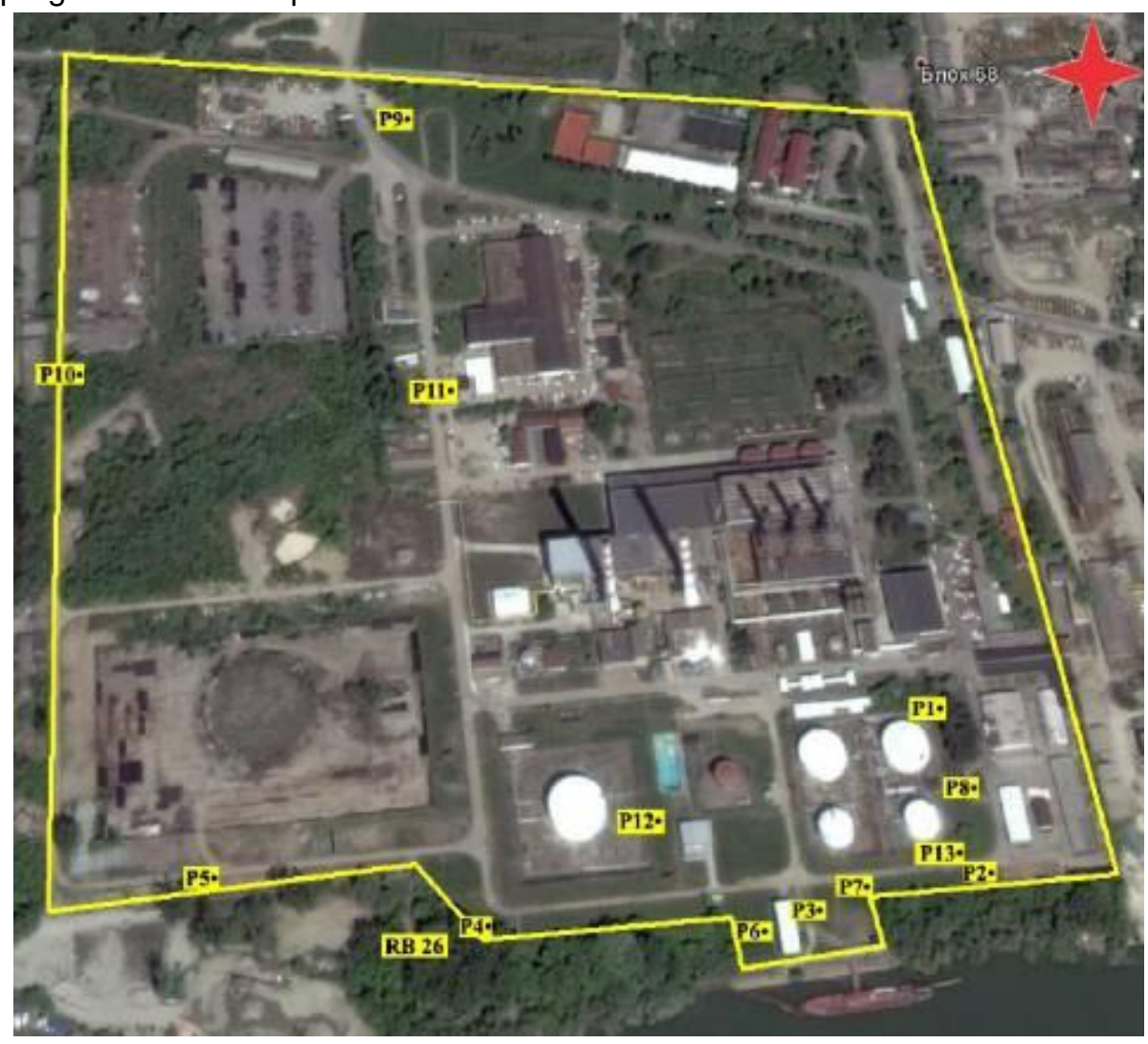

Figure 1 - Location of piezometers in the area of HP "Novi Beograd" 


\subsection{The physicochemical and chemical quality} parameters of underground water

The obtained results do not indicate any significant deviations or anything unexpected. All the analyzed samples are $\mathrm{pH}$ neutral or slightly basic, while the electrolyte content is higher in $\mathrm{P} 1$, Table 1 - Physicochemical and chemical quality parameters of underground water

\begin{tabular}{|c|c|c|c|c|c|c|}
\hline Sample & $\begin{array}{c}\mathrm{t}_{\text {air }} / \mathrm{t}_{\text {water }} \\
{\left[{ }^{\circ} \mathrm{C}\right]}\end{array}$ & $\begin{array}{l}\text { Turbidity } \\
\text { [NTU] }^{1}\end{array}$ & $\mathrm{pH}$ & $\begin{array}{c}\mathrm{k}^{2} / \mathrm{TDS}^{3} \\
{[\mu \mathrm{S} / \mathrm{cm} / \mathrm{mg} / \mathrm{L}]}\end{array}$ & $\begin{array}{c}\text { Dissolved } \\
\text { oxygen, [mg/L] }\end{array}$ & $\begin{array}{c}\mathrm{E}_{\mathrm{h}}^{4} / \mathrm{rH}^{5} \\
{[\mathrm{mV}]}\end{array}$ \\
\hline P-1 & $27,9 / 18,2$ & 0,59 & 7,04 & $1288 / 644$ & 1,92 & $412 / 28$ \\
\hline P-5 & $32,0 / 19,0$ & 0,96 & 7,10 & $661 / 330$ & 1,64 & $411 / 28$ \\
\hline $\mathrm{P}-6$ & $34,1 / 18,1$ & 1,03 & 7,16 & $458 / 230$ & 0,85 & $420 / 28$ \\
\hline $\mathrm{P}-7$ & $22,3 / 15,8$ & 1,02 & 6,93 & $615 / 312$ & 2,12 & $410 / 28$ \\
\hline$P-8$ & $32,1 / 19,1$ & 0,74 & 7,00 & $1009 / 505$ & 1,56 & $434 / 28$ \\
\hline P-9 & $28,6 / 17,8$ & 1,06 & 6,71 & $2070 / 1036$ & 1,42 & $377 / 26$ \\
\hline$P-10$ & $31,6 / 17,7$ & 1,02 & 7,37 & $740 / 370$ & 1,63 & $403 / 28$ \\
\hline P-11 & $30,6 / 20,2$ & 1,08 & 7,04 & $1810 / 904$ & 2,48 & $346 / 26$ \\
\hline P-12 & $28,6 / 18,5$ & 0,83 & 7,09 & $534 / 267$ & 1,84 & $415 / 28$ \\
\hline$P-13$ & $31,0 / 18,6$ & 0,62 & 7,00 & $778 / 386$ & 1,60 & $406 / 28$ \\
\hline Sava river & $26,2 / 18,6$ & 1,16 & 7,96 & $371 / 185$ & 3,33 & $418 / 30$ \\
\hline
\end{tabular}

${ }^{1}$ Normal Turbidity Unit, ${ }^{2}$ Conductivity, ${ }^{3}$ Total Dissolved Solids, ${ }^{4}$ Redox potential. For calibration is used the redox buffer $(\mathrm{Eh}=406 \mathrm{mV}(\mathrm{pH}=7)),{ }^{5}$ Redox factor-connects the redox potential and $\mathrm{pH}$. $\mathrm{rH}$ of redox buffer is 28 .
P8, P9 and P11, and the lowest in Sava River (Table 1.). Regarding dissolved oxygen, results show that underground water samples are poorly aerated; however, in relation to $\mathrm{rH}$, these samples are on the lower aeration limit.

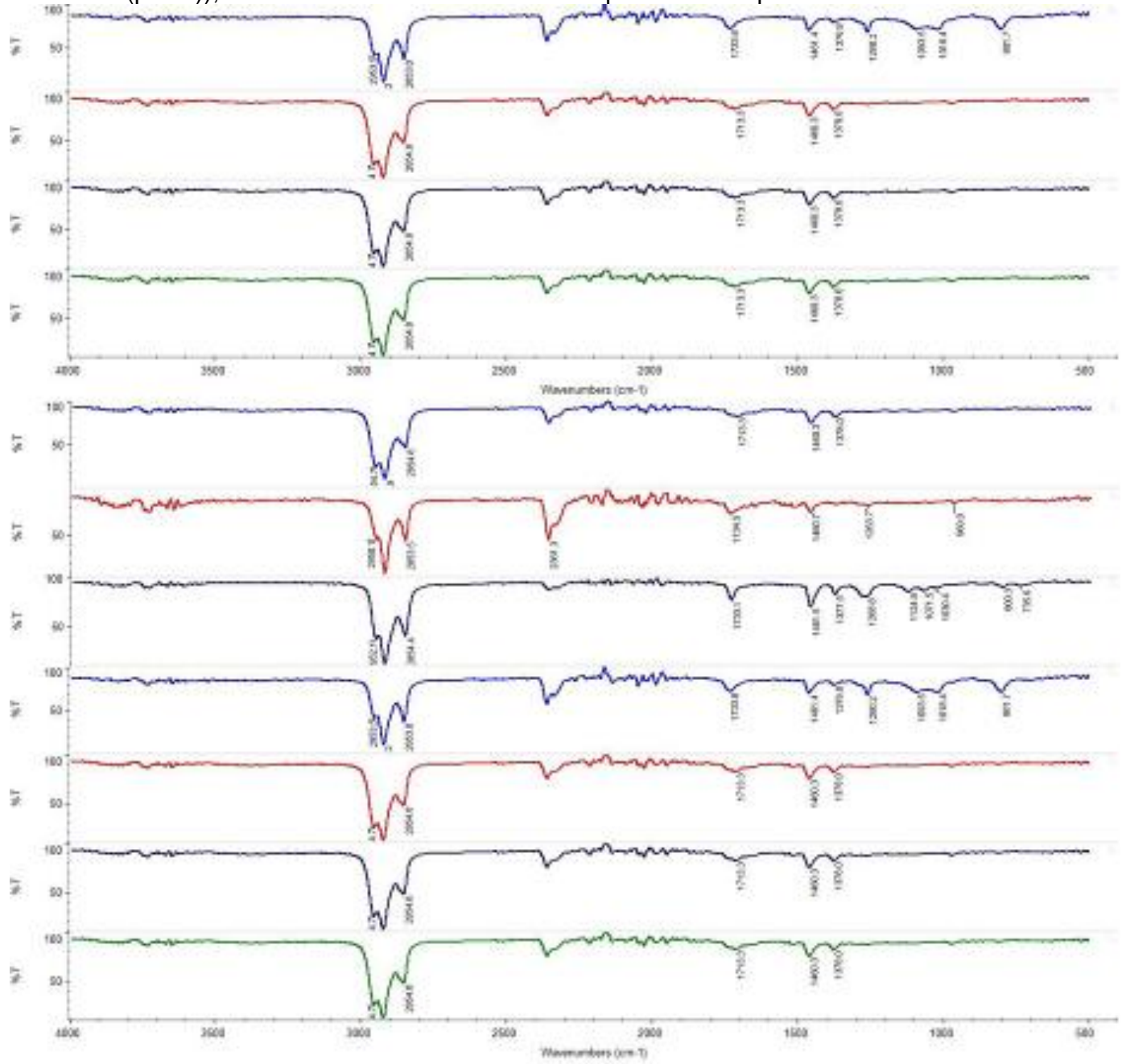

Figure 2 - The hexane-extractable organic substance from underground water samples 


\subsection{Structure of hexane-extractable organic substance from underground water samples based on FTIR-ATR spectrum}

The spectra indicate a dominant presence of petroleum pollutants. Area $4000-3500$ and area between 1700 and $1750 \mathrm{~cm}^{-1}$ show signals characteristic for oxygen functionalization of petroleum hydrocarbons, which is, in most cases, a consequence of microbiological aerobic transformations (Figure 2).

\subsection{Total petroleum hydrocarbons as pollutant indicators}

According to national legislation [5], remediation value for petroleum hydrocarbons i.e. mineral oils in underground water is $0,6 \mathrm{mg} / \mathrm{L}$, which means that "contaminated zone" is verified in piezometers P5, P6, P7, P8, P12 and P13 (Table 2).

Obtained concentrations of petroleum hydrocarbons were used for constructing the model distribution of pollutants in underground water. Modeling was performed using software "Groundwater Visitas V6-ADV" (Figure 3).
Table 2 - Total petroleum hydrocarbons in analyzed samples

\begin{tabular}{|c|c|}
\hline Sample & TPH $(\mathbf{m g} / \mathbf{L})$ \\
\hline P-1 & 0,21 \\
\hline P-5 & 1,39 \\
\hline P-6 & 1,76 \\
\hline P-7 & 1,57 \\
\hline P-8 & 0,65 \\
\hline P-9 & 0,32 \\
\hline P-10 & 0,39 \\
\hline P-11 & 0,23 \\
\hline P-12 & 0,70 \\
\hline P-13 & 1,22 \\
\hline Sava river & 0,37 \\
\hline
\end{tabular}

Figure 3 - Map of distribution of water pollution in the examined area with isolines of pollutant concentrations. The arrow shows the direction of movement of water

Considering the fact that it is not possible to precisely determine the quantity of contaminated water in the examinated area based on the stationary models, the only possible quantification method is by using the volumetric analysis. Twodimensional contours are correlated with the contaminated zone. Height of the water column which was taken into account is up to $15 \mathrm{~m}$, considering the fact that it is the final depth of the deepest boreholes used for examination. The total predicted volume of contaminated water by this model is around $105.000 \mathrm{~m}^{3}$ [4]. 
It is important to note that this value is only a rough approximation of the total volume of contaminated water, bearing in mind that water in which, due to the attenuation, the concentration of petroleum carbohydrates is not greater than 0,6 $\mathrm{mg} / \mathrm{L}$, was not taken into account.

In order to determine the exact type of petroleum pollutant, several petroleum derivates stored and used as fuel or for other purposes in HP "Novi Beograd", were analyzed by gas chromato- graphy, and the obtained spectra were compared with spectra of total petroleum hydrocarbons isolated from underground water.

Analyzed petroleum derivates include: Crude oil (CO), EcoDiesel (ED), Universal Mineral Oil (UMO) for 'Modrica" engines, mixture of diesel fuel/mineral oil 1:1 (DM) (BAM- Bundesanstalt für Materialforschung und -prüfung/Federal Institute for Materials Research and Testing, Analytical Standard) and Heavy oil (HO) (Figure 4).
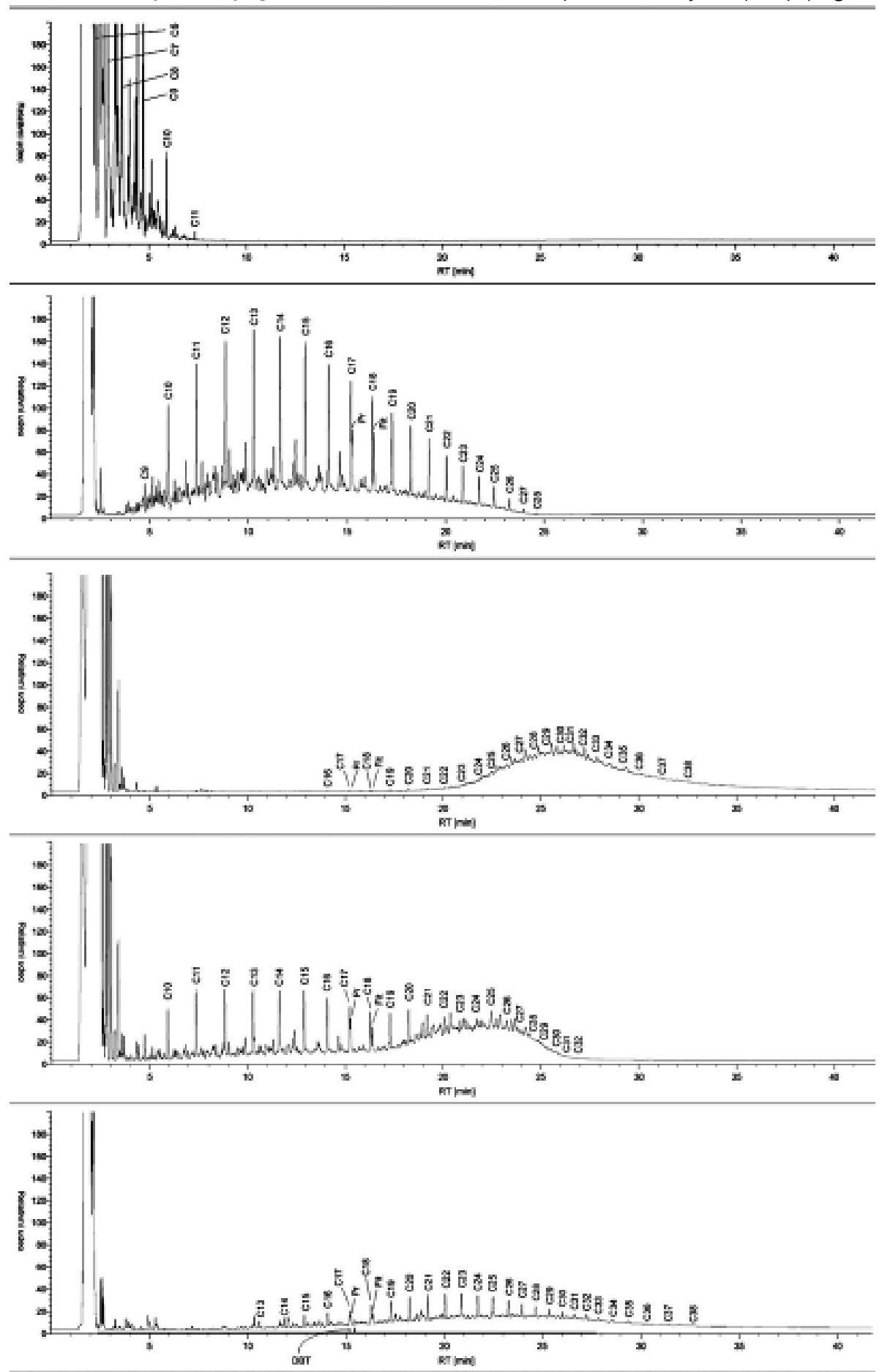

Figure 4 - Gas chromatograms of the "standards" CO, ED, UMO, DM and HO arranged from top to bottom 
Numbers located next to " $C$ ", which mark the signals, indicate the number of C-atoms of $n$ paraffin. Signals marked with $\mathrm{Pr}$ and Fit come from isoprenoid hydrocarbons pristane (C19) and phytane (C20), which are biomarkers of petroleum and its derivates, all except benzene, and in environmental and forensic chemistry they represent an evidence that pollutants are petroleum-originated.

Figure 5. shows chromatogram of collective sample of TPH from piezometers in which "contaminated zone" was confirmed (P5, P6, P7, P8, P12 and P13).

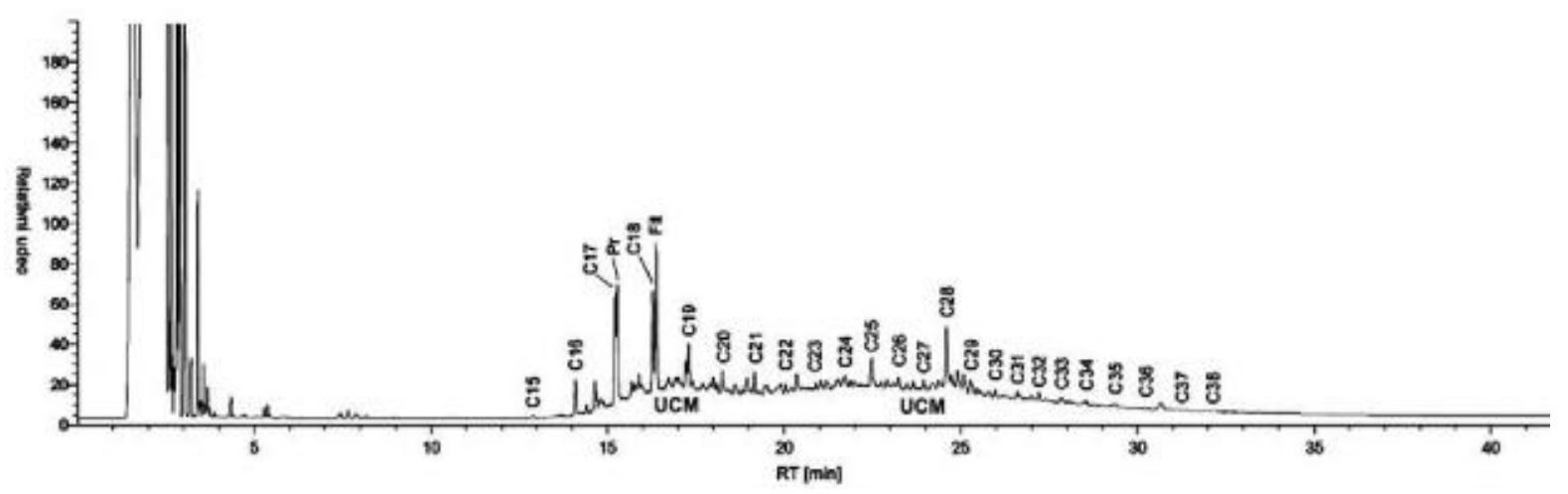

Figure 5 - The chromatogram of collective sample of TPH from piezometers in which "contaminated zone" was confirmed (P5, P6, P7, P8, P12 and P13)

Two parts, marked with UCM, which indicates an Unresolved Complex Mixture, can be seen on the obtained chromatogram, i.e. each of the two UCM corresponds to a unique type of petroleum pollutant or fuel, which implies that two types of petroleum pollutants are present in the underground water.

If we compare this chromatogram with standards shown in Figure 4. it can be seen that it represents a mixture of ED and $\mathrm{HO}$.

\subsection{Microbiological indicators and bioremediation potential of underground water}

Microorganisms (MO) are a significant evidence and indicators in forensic environmental chemistry. The most important groups of microorganisms were tested: total chemoorganoheterotrophs (TC), total anaerobes (TAN), yeasts and molds (YM), microorganisms which decompose hydrocarbons (HD). Results of microbiological examination of underground water and river water are shown in Table 3.

Table 3 - Results of microbiological examination of underground water and river water

\begin{tabular}{|c|c|c|c|c|c|c|}
\hline \multirow{2}{*}{ Uzorak-P } & \multicolumn{5}{|c|}{ MICROORGANISMS, [CFU/mI] } & \multirow{2}{*}{ BRP ${ }^{3}$, [ \%] } \\
\cline { 2 - 6 } & TC & TAN & YM & HD & Total microorganisms $^{2}$ & \\
\hline 1 & $4,0 \times 10^{4}$ & $1,8 \times 10^{5}$ & $6,7 \times 10^{3}$ & $8,6 \times 10^{3}$ & $2,3 \times 10^{5}$ & 4 \\
\hline 5 & $1,4 \times 10^{5}$ & $5,8 \times 10^{5}$ & $1,6 \times 10^{3}$ & $5,0 \times 10^{4}$ & $7,2 \times 10^{5}$ & 7 \\
\hline 6 & $4,5 \times 10^{5}$ & $1,5 \times 10^{5}$ & $5,0 \times 10^{2}$ & $5,2 \times 10^{4}$ & $6 \times 10^{5}$ & 9 \\
\hline 7 & $1,6 \times 10^{5}$ & $8,3 \times 10^{4}$ & $1,0 \times 10^{2}$ & $2,7 \times 10^{4}$ & $2,4 \times 10^{5}$ & 11 \\
\hline 8 & $2,0 \times 10^{5}$ & $2,0 \times 10^{4}$ & $1,0 \times 10^{2}$ & $6,0 \times 10^{3}$ & $2,2 \times 10^{5}$ & 3 \\
\hline 9 & $3,8 \times 10^{5}$ & $7,5 \times 10^{4}$ & $<100$ & $<100$ & $4,6 \times 10^{5}$ & $<1$ \\
\hline 10 & $4,0 \times 10^{4}$ & $4,4 \times 10^{5}$ & $<100$ & $5,0 \times 10^{3}$ & $4,8 \times 10^{5}$ & 1 \\
\hline 11 & $1,1 \times 10^{4}$ & $1,0 \times 10^{5}$ & $1,0 \times 10^{2}$ & $3,1 \times 10^{3}$ & $1,1 \times 10^{5}$ & 3 \\
\hline 12 & $1,1 \times 10^{3}$ & $1,3 \times 10^{5}$ & $<100$ & $8,2 \times 10^{3}$ & $1,3 \times 10^{5}$ & 6 \\
\hline 13 & $8,8 \times 10^{4}$ & $1,2 \times 10^{4}$ & $<100$ & $4,0 \times 10^{3}$ & $1 \times 10^{5}$ & 4 \\
\hline Sava river & $3,0 \times 10^{3}$ & $2,5 \times 10^{4}$ & $<100$ & $1,6 \times 10^{3}$ & $0,3 \times 10^{5}$ & 5 \\
\hline
\end{tabular}

${ }^{1}$ All of the results are expressed as number of colonies - CFU (Colony Forming Units), that is, a number of living microorganisms or their spores in $1 \mathrm{~mL}$ of water, ${ }^{2}$ Total microorganisms, TC+TAN+YM

${ }^{3}$ Bioremediation potential (BRP) is a share of bacteria which degrade petroleum derivates and a total number of microorganisms expressed as percentages. 
It is important to stress out that BRP for piezometers which have TPH levels higher that remediation value (marked grey) is around $5 \%$ and higher, which is an acceptable condition for microbiological remediation [6,7].

\subsection{Choice of technology for remediation of the contaminated site}

Choice of technology for pollution remediation is based on information obtained during the preliminary examination tests. These tests need to answer the following questions: What is the chemical nature of pollutants at the contaminated site? What is the level of pollution and the dimensions of the polluted area? What is the limit concentration that needs to be achieved based on the national legislative? What is the available time period for decontamination? What is the risk level? What is the cost? [8].

Based on the obtained data [6] and the extensive literature $[7,9,10,11,12,13]$, it can be concluded that the most appropriate method for remediation of underground water in the area of HP "Novi Begrad" is in situ bioremediation. Bioremediation is efficient, cost-effective green technology where pollutants are biologically transformed into non-toxic compounds or they are completely broken down to carbon dioxide and water. Microorganisms are most commonly used as biological agents. Degradation is performed in cells of microorganisms, which first absorb a pollutant and then, thanks to their own enzimes systems, transform and degrade pollutant to less toxic compounds. Pollutants have a role of nutrients and energy source for growth and development of microorganisms.

The use of microorganisms as biological agents in bioremediation is continually increasing because of their biodiversity and their great catabolic capacity. Bioremediation process enables the optimization of biodegradation of pollutants, which is achieved by aeration, biostimulation (adding nutritional substances) and bioaugmentation (adding microorganisms). Bioaugmentation implies adding microorganisms which are previously isolated form contamination sites and mulitiplied in bioreactors and returned to the site of contamination. The use of microbial populations characteristic for specific area prevents introduction of external pathogenes during the remediation process, which decreases the risk of disturbing the environmental equilibrium of the remediation site and the surrounding area $[14,15,16,17]$. The above-mentioned technology is successfully applied for treatment of water ecosystems contaminated with petroleum hydrocarbons.

\section{CONCLUSION}

System designed for easier sampling of underground water enabled collecting samples and data used for chemical and microbiological tests in order to examine the quality of underground water on the site of HP »Novi Beograd«. Obtained results indicate that the area of piezometers P5 to P8, as well as P12 and P13 have a concentration of total petroleum hydrocarbons greater that the remediation value standardized as $0,6 \mathrm{mg} / \mathrm{L}$. It was also determined that the total volume of the contaminated underground water is around $105.000 \mathrm{~m}^{3}$. All of the above indicates that it is necessary to start the remediation of underground water contaminated with petroleum hydrocarbons and that the most appropriate remediation procedure for this site is in situ bioremediation.

\section{Acknowledgements}

This research was partially financed by the Ministry of Education, Science and Technological Development of the Republic of Serbia as a part of the Projects III 43004.

\section{REFERENCES}

[1] ISO 9377-2 (2000) International standard: water quality-determination of hydrocarbon oil indexPart 2: method using solvent extraction and gas chromatography ISO, Geneva.

[2] C.Löser, H.Seidel, A.Zehnsdorf, U.Stottmeister (1998) Microbial degradation of hydrocarbons in soil during aerobic/anaerobic changes and under purely aerobic conditions, Appl. Microbiol. Biotechnol., 49, 631-636.

[3] I.D.Bossert, L.M.Shor, D.S.Kosson (2002) Methods for measuring hydrocarbon biodegradation in soils, book Manual of Environmental Microbiology, second ed. ASM Press, Washington, p. 934-943.

[4] M.Vrvić, B.Jovančićević, S.Miletić (2015) Detailed examination of soil contaminated with hydrocarbons petroleum on the location of heating plant (Research of hydrochemical and geochemical processes and geomicrobiological and biogeochemical interaction in groundwater and surface water and soil (in Serbian).

[5] The regulation on the programme for the systematic monitoring of soil quality, soil degradation risk assessment indicators and methodology for the development of remediation programmes" (RS Official Gazette No88/2010 (in Serbian).

[6] N.Marić, M.llić, S.Miletić, G.Gojgić-Cvijović, V.Beškoski, M.M.Vrvić, P.Papić (2015) Enhanced in situ bioremediation of groundwater contaminated by petroleum hydrocarbons at the location of the Nitex textiles, Serbia, Environ. Earth. Sci., 74(6), 52115219.

[7] P.Bedient, H.Rifai, C.Newell (1999) Groundwater contamination transport and remediation, 2nd edn. Prentice Hall, Upper Saddle. 
[8] I.A.Mirsal (2008) Soil Pollution - Origin, Monitoring \& Remediation, $2^{\text {nd }}$ Ed., Springer.

[9] P.B.Hatzinger, M.C.Whittier, M.D.Arkins, C.W. Bryan, W.J.Guarini (2002) In situ and ex situ bioremediation options for treating perchlorate in groundwater, Remed. J., 12, 69-86.

[10] W.F.Talley, P.M.Sleeper (2006) Roadblocks to the implementation of biotreatment strategies, Annu. NY Acad. Sci., 829, 16-29

[11] D.Polomčić, V.Ristić Vakanjac (2011) Groundwater in water supply of Serbia-current state and perspectives, Faculty of Mining and Geology, Belgrade, p. 45-77.

[12] D.M.Mackay, J.A.Cherry (1989) Groundwater contamination: pumpand-treat remediation, Environ. Sci. Technol., 23, 630-636.

[13] U.S. EPA (1995) How to evaluate alternative cleanup technologies for underground storage tank sites: a guide for corrective action plan reviewers.
[14] M.llić, M.Antić, V.Antić, J.Schwarzbauer, M.Vrvić, B.Jovančićević (2011) Investigation of bioremediation potential of zymogenous bacteria and fungi for crude oil degradation, Environ. Chem. Lett., 9, 133-140.

[15] C.U.Uzochukwu, D.M.Jones, M.I.Head, A.C.D. Manning, I.C.Fialips (2014) Biodegradation of crude oil saturated fraction supported on clays, Biodegradation, 25(1), 153-165.

[16] V.P.Beškoski, G.Gojgić-Cvijović, J.Milić, M.llić, S.Miletić, T.Šolević, M.M.Vrvić (2011) Ex situ bioremediation of a soil contaminated by mazut (heavy residual fuel oil) - A field experiment, Chemosphere, 83, 34-40.

[17] G.D.Gojgić-Cvijović, J.S.Milić, T.M.Šolević, V.P.Beskoski, M.V.Ilić, L.S.Đokić, T.M. Narančić, M.M.Vrvić (2012) Biodegradation of petroleum sludge and petroleum polluted soil by a bacterial consortium: a laboratory study, Biodegradation, 23, $1-14$.

\section{IZVOD}

\section{MONITORING PODZEMNIH VODA - NEOPHODAN KORAK U UTVRĐIVANJU NAČINA SANACIJE KONTAMINIRANOG LOKALITETA}

Predmet ovog istraživanja je ispitivanje kvaliteta podzemnih voda na lokalitetu toplane "Novi Beograd" (Srdija). Istraživanjima je obuhvaćen sistem od 10 pijezometara $(P 1, P 5, P 6, P 7, P 8, P 9$, $P 10, P 11, P 12, P 13)$, koji su konstruisani u dva ciklusa (P1, P5, P6 i P13 do dubine od 10 metara $i$ od $P 7$ do $P 12$ do dubine od 15 metara).

Dobijeni rezultati pokazuju da je oblast u kojoj se nalaze pijezometri od P5 do P8, kao i P12 i P13, oblast u kojoj je koncentracija ukupnih ugljovodonika nafte veća od remedijacione vrednosti koja je normirana na 0,6 mg/L. Takođe, utvrđeno je da je ukupna zapremina kontaminirane podzemne vode oko $105.000 \mathrm{~m}^{3}$. Sve navedeno ukazuje da je neophodno pristupiti sanaciji podzemne vode kontaminirane ugljovodonicima nafte, kao i da je najoptimalniji postupak za navedeni lokalitet in situ bioremedijacija.

Ključne reči: podzemna voda, remedijacija, naftni ugljovodonici.

\section{Naučni rad}

Rad primljen: 13. 02. 2015.

Rad prihvaćen: 10.03.2016.

Rad je dostupan na sajtu: www.idk.org.rs/casopis 